\title{
In The Direction OF Finding the Way of a Responsible Theology for the Hungarian Reformed ChurCh (OF Transilvania)
}

\author{
DOI: $10.14232 /$ jp.pgy.2021.5
}

\section{INTRODUCTION -REASONS FOR WRITING THIS PAPER}

There are several reasons which lead me to write about this - sometimes troublesome - topic. It is uncomfortable because it deals with enormously sensible questions, and it is very difficult to find a really useful solution without hurting anyone.

The first reason which urged me to write is that I see that the number of the members of the Hungarian Reformed Church of Transylvania is decreasing. In the past 25 years, it has decreased by more than 100.000 people. The reasons of this decreasing tendency are of course manifold, but behind the decrement of births, the "conversion" to other neo-protestant or non-Christian religious denominations (Jehovah's Witnesses, New Age, Hit Gyülekezete ${ }^{478}$, Buddhism, and other oriental religions, etc) there is not only the freedom of human rights or some existential-empirical reasoning but a theological background as well.

Secondly, I see that especially after 1920, the new theological movements have arrived some years or decades later to Transylvania than to other European countries. Beside the fact that as a result of a range of betrayals, the European Transylvania was attached to a Balkan state, the Reformed Church was for half a century long period under communist oppression (between 1948-1989), which delayed its catching-up with contemporary theological movements even more. For example, the Systematic Theology by Paul Tillich was translated into Hungarian only in 1996, or the Systematic Theology by Wolfhart Pannenberg in 2005.

The third reason is somewhat more general. In the past 25 years, some significant works of modern theology have been translated into Hungarian, but there has been no authentic Hungarian theology written. The few attempts which have been made in this direction did not have an echo among Hungarian theologians. With this assertion I would like to accentuate that translations of significant theological works are important, but having and reading only translations could cause a non-desired dependence on the Western theology. Instead of this dependence, it is highly necessary to elaborate a contextualized theology of the Hungarian Reformed Church (of Transylvania).

\footnotetext{
478 In English translation it is "the Faith Church of Hungary". It is a religious movement (according to the official point of view: church) with Roman Catholic and Pentecostal background, and it has about 160000 believers. It is a strong advocate of Christian Zionism, and well known for its commitment to support the State of Israel.
} 
Furthermore, only a few Hungarian theologians are present in the international theological science. This could lead to an isolation of the Hungarian theological science. Instead of isolation, the Hungarian reformed theology needs to find its own voice and thus be integrated in the international scientific life of theology. This statement, however, has large implications. It requires first of all a more agile scientific activity from the part of Hungarian theologians and on the other hand, a constructive critical openness from the part of the Western theological elite.

By mentioning these, I am not saying that there are no theological works in the Hungarian Reformed Church of Transylvania or to underestimate the theological activity which is already done but I only highlighted some aspects which - at least in my opinion - could be an obstacle in the way of doing theology.

The following considerations are like an attempt to draw the contours of a methodology of doing theology which would help the Hungarian Reformed Church of Transylvania to become an organic member of the international theological life.

\section{WhAT IS THEOLOGY? - THE PATH FROM "DOCTRINA DE DE0" TO "DOCTRINA DEO VIVENDI"}

I think one of the most important duties in the renewal and improvement of doing theology is to (re)define what theology exactly is. I find this definition rather important because the way of thinking about the essence and object of the field of research (which is theology in this case) determines the methodology and the way of research, and could have a serious influence on the results as well.

Almost all definitions of theology start with the etymological analysis of the Greek word $\theta \varepsilon o \lambda o \gamma i \alpha$. The first part of this compound word is $\theta \varepsilon$ ós, which means God, while the second part ( $\lambda$ ơós) has several meanings. First of all, it means "word", but it can denote "opinion", "surmise" or "reasoning" as well. In the early Christian context, it denoted the Word of God, the eternal Logos, i.e., Jesus Christ. It is important to see that the term "theology" did not emerge in an originally Christian context: it came in the Christian word-usage from the ancient pagan writers. According to Aris-

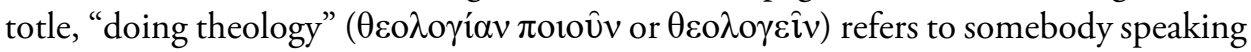
about gods or about things related to gods, while in the works of Plutarch, it denotes the research of the "divine topics". ${ }^{479}$ The Swiss Reformed theologian Benedict Pictet (1655-1724) remarks that in the works of ancient pagan savants the term of theology was used in a threefold context: ${ }^{480}$

479 Györkösy - Kapitánffy - Tegyey: Ógörög-magyar nagyszótár (Ancient Greek - Hungarian Dictionary). Akadémiai Kiadó (Academic Publisher House), Budapest 1993. 496.

480 Pictetus, Benedictus: Medulla Theologiae Christianae Didacticae et Elencticae. Geneva 1711. 2. 


\section{$>$ "theologia fabulosa" or "mythica" denoted the theology of poets; \\ $>$ "theologia naturalis" denoted the theology of philosophers; and \\ $>$ "theologia politica et civilis" denoted the theology of priests.}

Taking a look at how ancient Christian writers interpreted the word theology might have an awakening effect. Alister McGrath offers a very clear overview, and as to an ancient witness he refers to Tertullian, according to whom theology is reflection upon the God whom Christians worship and adore. ${ }^{481}$ Augustine states that theology is the reasoning or speaking concerning Deity (de divinitate rationem sive sermonem). ${ }^{482}$ According to these, the earliest Christian writers used the word "theology" as a term to describe a systematic analysis of God's nature, intentions and deeds. ${ }^{483}$

The later definitions of theology were based on the definition of the Church Fathers, but its content is permanently growing: under the influence of Peter Abelard and Gilbert of Poitiers, the Latinized word theologia means "the discipline of sacred learning, embracing the totality of Christian doctrine, and not merely the doctrine of God". 484 The next important change in the interpretation of theology came more recently, during the time of Enlightenment. Then "attention has shifted toward the study of the human phenomenon of religion; "Religious studies" or "the study of religions" concerns investigating religious matters". ${ }^{485}$

The $20^{\text {th }}$ century brought afresh an important change in the meaning of theology. The neo-orthodox theologians began to define again the essence of theology using the classical definition. Now we will present some definitions of theology from this period. According to Karl Barth, theology as a science is a measure taken by the Church whose goal is self-examination. ${ }^{486}$ István Török, one of the Hungarian disciples of Barth defines theology as a science which somehow apprehends, cognizes, understands and resounds God. ${ }^{487}$ Sándor Tavaszy (1888-1951), a Transylvanian theologian who was influenced by Barth, but who tried to apply Barth's recognitions to the Transylvanian context after the $1^{\text {st }}$ World-War, defines theology as a science which was created within and by the Christian Church. Its goal is to arrange God's Revelation within conceptual-reflective forms and to propound it with scientific systematism. ${ }^{488}$ The definition

481 McGrath, Alister: Christian Theology. An Introduction. 5th edition. Wiley-Blackwell, 2011. 158.

482 Augustinus: De civitate Dei. VIII,1.

483 McGrath, Alister: Bevezetés a keresztény teológiába (Christian Theology. An Introduction. 1st edition). Osiris Kiadó, Budapest 1995, 121.

484 McGrath, Alister: Christian Theology. An Introduction. 5th edition. Wiley-Blackwell, 2011. 158-59.

485 McGrath, Alister: Christian Theology. An Introduction. 5th edition. Wiley-Blackwell, 2011. 159.

486 Barth, Karl: Church Dogmatics. I/1. (eds.: G. W. Bromiley - T. F. Torrance) T\&T. Clarck, Edinburgh 1975. 4.

487 Török István: Dogmatika. Protestáns Teológiai Intézet, Kolozsvár 2006. 15.

488 Tavaszy Sándor: Református keresztyén dogmatika. Protestáns Teológiai Intézet, Kolozsvár, 2006, 15. 
by the Roman-Catholic theologian Karl Rahner is affined with the last one, according to whom theology as a "science of faith" is "the conscious and methodical explanation and explication of the divine revelation received and grasped in faith" ${ }^{489}$

We pointed out the above-mentioned definitions of theology because these theologians had a serious influence on doing theology in the Hungarian Reformed Churches of Hungary and Transylvania. Adapting the neo-orthodox approach of doing theology instead of the liberalism of the $19^{\text {th }}$ century was also a positive aspiration. I think this heritage, due to its revelation-centrism, could be an effective help of the Hungarian Reformed theology in finding its own voice in the $21^{\text {st }}$ century. In this context we could agree with the definition of theology as it is formulated by Paul Tillich. According to him, theology is a function of the Christian Church which came into being in order to fulfil two essential needs of the Church: on the one hand, it has to establish the truth of the Christian message, and on the other hand, it has to interpret it for every coming generation. ${ }^{490}$

While we try to define theology in the context of the Hungarian Reformed Church of Transylvania, we should see the implications of the historical background of the last decades (especially between the years 1948-1990). In this period the state wanted to subordinate Church to its own goals, especially to the propagation of the communist ideologies. This "Sitz im Leben" has its effects nowadays as well and therefore, theological science in the Hungarian Reformed Church of Transylvania must be on the alert in order to defend and to preserve its independency. The most important factors which threaten the independency of the Reformed theological science are on the one hand the Balkan mentality of the Romanian state and the influence of Eastern Orthodox Church which is tacitly recognized as state-religion; while on the other hand, the church-politics could also hold some dangers of the kind.

The discriminatory approach of the Romanian state becomes obvious especially when almost all scientific grants for doing theology are given to Eastern Orthodox theologians. In this situation Reformed theologians have to work within very limited scientific and financial possibilities. The most important danger which comes from the Eastern Orthodox church and which is to be prevented by Reformed theologians is its methodology of shaping dogmata. In the Eastern Orthodox practice of shaping dogmata tradition has a determinant role. For example, a widely practiced form of "piety" accepted by the "Holy Synod" could become a dogma. The canonization of many of their (often political) saints (Bishop Andrei Saguna) happened in this way.

In this context, it is especially important to see very clearly that theological science has two aspects: an immanent and a transcendent aspect. If one's attention is limited only to the immanent aspect of theology, they could easily fall for the above-presented 
dangers, and become the deservers of immanent (political, personal, etc.) interests. But ignoring the transcendent aspect of the theological science has other consequences as well. Focusing only on the immanent aspect of theology could lead us back into the period of liberal theology of Enlightenment when theological science was rather a study of religions than genuine theology.

Reckoning with the transcendent aspect of theology, it becomes obvious that theological science could process that information which God has revealed about Himself. In such a way God is not only the object of the theological science but He is its subject as well. He is the one who creates the opportunity of research through which theologians have to find the perpetual but at the same time, also actual (relevant) answer for the existential questions of humanity. In order to emphasize the transcendent aspect of the theological science, I deem it necessary to read again the definition of theology given by the $17^{\text {th }}$ century scholar, Amesius: „Theologia est doctrina Deo vivendi... Doctrina vocatur, quia haec disciplina non est ex natura et indagine humana, sed ex revelatione et institutione divina. ${ }^{3491}$ The roots of this approach can be found in the Early Christian Literature as well. For example, according to Clemens of Alexandria, theology is not only the doctrine (teaching) concerning the Logos but the teaching about God revealed by the eternal Logos. ${ }^{492}$ This approach found its way into the Hungarian theological life through the translation (or paraphrases) of the Medulla theologica by Amesius, by one of his Hungarian students Martonfalvi Tóth György: ${ }^{493}$

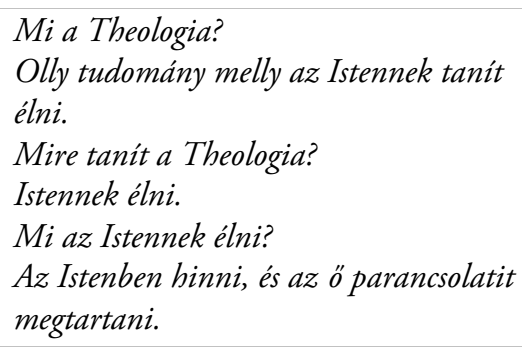

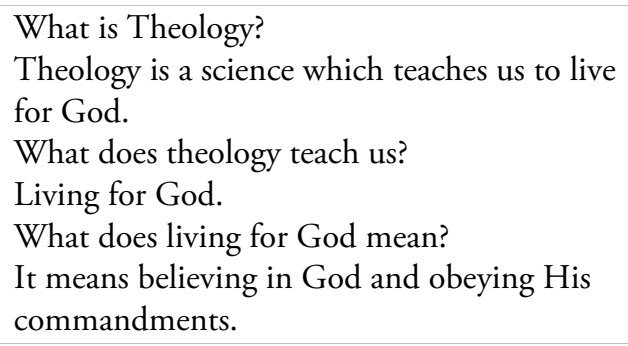

This practical (or piety-oriented) definition of theology is still obvious in the Institutes of Calvin as well. When he writes that the true wisdom consists almost entirely of the knowledge of God and of ours (Inst I 1,1), by unfolding his statement he latently suggests that believers through this double knowledge have to learn to act right (i.e., conform to the requirements of God's Law). I think that this is the final goal of each branch of theological science. With a high scientific accuracy and undiminished fidelity

491 Amesius, Guilelmus: Medulla Theologica illustrata. Franequerae 1670. 5.

492 See: Pannenberg, Wolfhart: Rendszeres teológia, 1. Kötet (Systematic Theology. Volume I). Osiris Kiadó, Budapest 2005, 11.

493 Martonfalvi Tóth György: Tanétó és Czáfoló theológiája. Debrecen, 1679, 1-2. 
to God's Revelation, theological science has to give instruments into the hands of ministers and pastoral workers which could help them to "win also others to Christ". ${ }^{494}$

This approach of theological science fits almost perfectly in the "five-act drama model" of N. T. Wright in which Jesus is the central character. ${ }^{495}$ According to this approach, the history of salvation (and within it the history of humanity and of the Church) is like a Shakespeare-play which lost its fifth act. About the description of the acts of the play, Wright writes as follows:

When we read Genesis 1-2, we read it as the first act in a play of which we live in the fifth. When we read Genesis 3-11, we read it as the second act in a play of which we live in the fifth. When we read the entire story of Israel from Abraham to the Messiah (as Paul sketches it in Galatians 3 or Romans 4), we read it as the third act. When we read the story of Jesus, we are confronted with the decisive and climactic fourth act, which is not where we ourselves live, [...] but which, of course, remains the foundation upon which our present (fifth) act is based. ${ }^{496}$

Wright states that the climax of this play is the story of the Messiah, and he calls the fifth act "the Spirit-driven Church" ${ }^{497}$ I am aware that according to Kevin Vanhoozer, the order of the acts should be modified. In his opinion, the Fall is not an independent phenomenon, but it is rather the conflict in the first act. Therefore, he recommends the following order: creation, election of Israel, Christ, Pentecost and the church, consummation. ${ }^{498}$ I however do not find this modification necessary because in my opinion, the consummation fits perfectly into the fifth act of Wright's partition as the glorious future of the "Spirit-driven Church".

According to Wright, living in the fifth act has many implications: ${ }^{499}$

$>$ First, we have to be conscious of living as people through whom the narrative in question is now moving towards its final destination.

$>$ Secondly, we have to be aware that our relationship to the New Testament is not the same as our relationship to the Old one, and that we can state this

494 See: Heidelberg Catechism, Art. 86.

495 More details about this model can be found in: Wright, N. T.: How Can the Bible Be Authoritative. Source: http://ntwrightpage.com/Wright_Bible_Authoritative.htm (accessed: 30. 10. 2014.); Wright, N. T.: Scripture and the Authority of God. Harper Collin's ebooks. Chapter 8.

Wright, N. T.: The New Testament and the People of God. Fortress Press, Minneapolis 1992. 131-44.

496 Wright, N. T.: Scripture and the Authority of God. HarperCollin's ebooks. Chapter 8.

497 In his lecture about "Biblical authority" held on 30-10-2014 at the Theological University of Kampen.

498 Vanhoozer, Kevin: A Drama-of-Redemption Model. In: Meadors Gary (ed): Four Views on Moving Beyond the Bible to Theology. Zondervan, Grand Rapids 2009. 174.

499 Wright, N. T.: Scripture and the Authority of God. HarperCollin's ebooks. Chapter 8.. In the following we shall quote the most important implications of Wright's model, but we will not mark them in separate footnotes. 
with no diminution of our commitment to the Old Testament as a crucial and non-negotiable part of "holy scripture".

$>$ Then, we have to see very clearly that the New Testament is the base chapter of the fifth act. No change of act in God's drama with the world (despite manifold changes in human culture) has occurred between the time of the apostles and evangelists and our own; there is nothing that would correspond to the great double change of act (from Act 3 to Act 4, and from Act 4 to Act 5) which occurred between their time and that of Torah, Prophets and Writings.

> We who call ourselves Christians must be totally committed to telling the story of Jesus both as the climax of Israel's story and as the foundation of our own. We recognize ourselves as the direct successors of the churches of Corinth, Ephesus, and the rest, and we need to pay attention to what was said to them as though it was said to us.

$>$ The New Testament offers us a glimpse of where the story is to end: not with us "going to heaven" as in many hymns and prayers but with new creation.

In conformity with these characteristics of God's great narrative,

our task is to discover, through the Spirit and prayer, the appropriate ways of improvising the script between the foundation events and charter, on the one hand, and the complete coming of the Kingdom on the other. Once we grasp this framework, other things begin to fall into place..$^{500}$

Here Wright remarks that "improvising” presupposes - like in music -

a disciplined and careful listening to all the other voices around us, and a constant attention to the themes, rhythms, and harmonies of the complete performance so far, the performance which we are now called to continue." 501

Accordingly, "all Christians, all churches, are free to improvise their own variations designed to take the music forward. No Christian, no church, is free to play out of tune". ${ }^{502}$

According to the terms of this model, (each department of) theological science gives instruments in the hands of ministers and pastoral workers through which they would be able to 

... the Way of a Responsible Theology for the Hungarian Reformed Church

show believers and other inquiring persons that the story of Christ and of the Scripture is the framework of our stories;

$>$ help them see how the Great Narrative of God sheds light on the present situation;

$>$ help them interpret their own stories in the light of the Great Narrative of God;

$>$ help them (re)find their own stories as part of God's drama.

\section{THEOLOGICAL SCIENCE IN ITS RELATION-SYSTEM: GOSPEL - CHURCH - BELIEVER}

After we presented the definition of theological science concerning its piety-oriented purpose, we have to shift to the summarizing of some other essential characteristics of the Reformed Christian theology.

Here we need to turn our attention to the famous German theologian Eberhard Busch, who deals with the characteristics of the Christian reformed theology in the introduction of his explanation on the Heidelberg Catechism. Writing about the task of the theology, he states that the first question of the Heidelberg Catechism, i.e., "What is your only comfort?" could be taken as the basic question of doing theology. Busch interprets the word "comfort" as "a kind of summary of what is involved in the Christian confession of faith, which theology reflects on". ${ }^{503} \mathrm{He}$ argues that the most fruitful way of answering this question is to see that "the one who puts this question to us is first and last God". ${ }^{504}$ This way, doing theology can be explained as trying to find an answer to a divine question:

Theology in this context is a special human undertaking to listen to this question posed by God, and to try to answer it. ${ }^{505}$

But it is very important - according to the author - to recognize that God has already made a beginning with us by preparing such a comfort for us. ${ }^{506}$ Furthermore, it must be seen clearly that theology does not have to invent the answer but instead, it has "to discern the answer already given along with the question God puts to us, to express this answer in its own words, and to reflect on the answer". ${ }^{507}$ Thus, the duty of theology is a response to God's initiative. This is the only way it can on the one hand prevail to

503 Busch, Eberhard: Drawn to Freedom. Christian Faith Today in Conversation with the Heidelberg Catechism. (transl. Rader, William), Eerdmans, Grand Rapids - Cambridge 2010. 1. (In the followings: Busch, Eberhard: Drawn to Freedom.)

504 Busch, Eberhard: Drawn to Freedom. 2-3.

505 Busch, Eberhard: Drawn to Freedom. 3.

506 Busch, Eberhard: Drawn to Freedom. 3.

507 Busch, Eberhard: Drawn to Freedom. 3. 
find itself without object and on the other hand, it can be a meaningful and promising activity. $^{508}$

When he states that "we cannot seek without [...] having been found by God", 509 it means - at least according to my interpretation - that faith in God, who sets the question and also prepares the answer, is a prerequisite of doing theology. This track, however, has serious implications which must be observed in order to remain within this frame which could guarantee the safety of the theological science:

$>$ First of all, no one should forget that the object of Christian theology is the Gospel. ${ }^{510}$ Here Busch defines Gospel as a message which "is spoken to me, and which I cannot tell myself". The internal nature of this message is that "once spoken to us, we become dependent on: we need to have it spoken to us again and again". This way, Christian theology "is about the relation between God and humanity".

> Secondly, "it is indispensable for Christian theology that it is oriented to Holy Scripture and that it is formed through scripture's witness". ${ }^{511}$ This way, theology is inseparable from Bible as the primary and unsurpassed witness of its story. But Christian theology should not use Holy Scripture through the filter of human wishes which function like some blinders.

At this point we have to insert the reformatory thesis: "sola Scriptura". As Michael Welker quotes, the expression has its origins in Martin Luther's works who stated that the "Scripture alone ... shall be the queen! Scripture shall be queen among the oral and written testimonies to God and God's creative will!" 12 Welker underlines that Luther's assertion about the Scripture as "queen" means also that the Holy Scripture is "only queen" - but not King, or God. It is "God's word in human language and in human ways of seeing". ${ }^{513}$ Therefore, Luther repeatedly warned against turning the Bible into a 'paper pope' as well as the other Reformers.

Welker mentions also that the North American Reformation historian David Steinmetz drew the attention to the fact that the Reformers generally understood sola scriptura as scriptura valde prima. ${ }^{514}$ This expression could be translated as "the Scripture is

508 Busch, Eberhard: Drawn to Freedom. 4.

509 Busch, Eberhard: Drawn to Freedom. 3.

510 Busch, Eberhard: Drawn to Freedom. 4. The passages in “...” of this paragraph are quotations of the same page of this book; therefore we will not mark them in different footnotes.

511 Busch, Eberhard: Drawn to Freedom. 5.

512 Welker, Michael: Sola Scriptura? The Authority of the Bible in Pluralistic Environments. In: Strawn, B. A. - Bowen, N. R. (eds.): A God So Near. Essays on the Old Testament Theology in Honor of Patrick D. Miller. Eisenbrauns, Winona Lake 2003. 377. (In the following: Welker, Michael: Sola Scriptura? The Authority of the Bible in Pluralistic Environments.)

513 Welker, Michael: Sola Scriptura? The Authority of the Bible in Pluralistic Environments. 377n1.

514 Welker, Michael: Sola Scriptura? The Authority of the Bible in Pluralistic Environments. $377 \mathrm{n} 1$. 
the first above all" or "the Scripture foregoes everything". According to Botond Gaál, ${ }^{515}$ this interpretation of "sola Scriptura" implies delimitation on the one hand from the Roman-Catholic authority-centred approach and on the other hand, from the fundamentalist interpretation of the Bible. ${ }^{516}$ It means that the reformers were aware of the immanent aspects of the Holy Scripture as well, and this awareness determined their approach to the Bible's primacy. According to them, the Scripture is not equal with the truth but it is a witness of the Truth. In this quality, the intellectual and spiritual elaboration of God's Revelation stands above all.

The Scripture tells us what (or more precisely who) the truth is - and we have to find or discern it through the work of the Holy Spirit. ${ }^{517}$ In Botond Gaál's assertion we

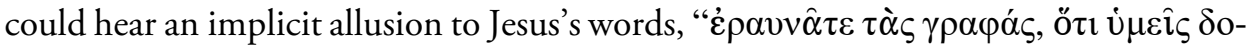

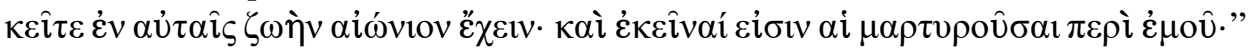
(John 5,39). Through this work of the Holy Spirit (which among others has as instruments the methods of the text-analysis, the studying if the history, the works of the Church Fathers) ${ }^{518}$ could happen that from the Bible, in spite of its immanent characteristics, one could listen to it "as having sprung from heaven, as if there the living words of God were heard”. ${ }^{519}$ Rethinking Calvin's argumentation concerning the authority of the Holy Scripture, we can state that according to this logic, it is not the believer who has the freedom of the interpretation of the Bible but the believers have the possibility to experience the infinite freedom of God's Word - through the power of the Holy Spirit. This way - says Botond Gaál in his quoted paper - the principle of sola Scriptura becomes a "norm" of doing theology in a disciplined manner. ${ }^{520}$

$>$ Furthermore, Christian theology is connected to the Christian Church. ${ }^{521}$ It means that Christian theologians cannot ignore the fact that they are members of the Christian church, and therefore "do not do theology as neutral observers". Busch underlines that he does not say "should not ignore it" but "cannot ignore it". In this context, theology as theory is "neither the mother nor the ruler but the servant of Christian faith and life in the Church".

515 Botond Gaál (born 1946), PhD, DSc, is the former ordinary professor of Dogmatics at the Reformed Theological University of Debrecen (Hungary). -

see: https://silverprince99.wixsite.com/bgaal-eng/about_us (accessed 07. 05. 2021.)

516 Gaál Botond: Scriptura valde prima.

Source: https://silverprince99.wixsite.com/bgaal/tanulmny-41 (accessed: 07. 05. 2021.)

517 Gaál Botond: Scriptura valde prima.

518 We have enumerated only a few "instruments", which Calvin also has used in order to understand better the message of the Holy Scripture.

519 Calvin, John: Institutes of the Christian Religion I 7,1. (tr. Battles, F. L.), Westminster Press 1960. 74.

520 Gaál Botond: Scriptura valde prima.

521 Busch, Eberhard: Drawn to Freedom. 6. 
Theology is an activity in which "I myself am always called to accountability". ${ }^{22}$ Theologians cannot do theology without realizing: "tua res agitur" -, and that we are ultimately liable to God.

> Finally - according to Busch - theology is an incomplete activity. ${ }^{523}$ That means on the one hand that its activity takes place within a certain limit on the earth, while on the other hand, unavoidably under the proviso that we may be taught better through Holy Scripture. But in spite of its limits, it is a joyful activity because the promise of the kingdom of God is "what gives us strength not to let our hand sink from the plow for at least the next step". This way, "Ora et labora!" could not be separated in theology. So "theology is necessarily also this: a praying discipline, praying for what it cannot give itself".

On behalf of its primary connection to the Bible and to the Christian Church, the main task of theology has to tell the Drama of Redemption as clearly and as precisely as possible, in order to find the answer to four elementary questions which could help believers achieve a better knowledge about God and themselves. These four questions and answers - according to N. T. Wright - are: ${ }^{524}$

$>$ Who are we? - Humans, made in the image of the Creator.

$>$ Where are we? - In a good and beautiful, though transient world, made by our Creator.

$>$ What is wrong? - The rebellion of humans against their Creator.

$>$ What is the solution? - The creator acted, acts and will act to bring the world to the end for which he created it. This action is focused on Jesus Christ and the Spirit of the Creator.

Although these answers are formulated in a general language, they are able to show the direction which Christian theology has to follow in order to fulfil its primary task: to "win also others to Christ" and to become an instrument of the Holy Spirit in growing the community of "Kingdom-people". 525

\section{ConcLusion}

In this paper I tried to present some aspects of the theological science which I considered important for the permanent renewal of doing theology in the Hungarian Re-

\footnotetext{
522 Busch, Eberhard: Drawn to Freedom. 7.

523 Busch, Eberhard: Drawn to Freedom. 8.

524 Wright, N. T.: The New Testament and the People of God. Fortress Press, Minneapolis 1992. 132-33.

525 "Kingdom-people" is an expression used by Tom Wright, through which he characterizes Christians who are aware that Jesus is the only genuine King of the world and confess His exclusive Lordship.
} 
formed Church of Transylvania. I am aware that this presentation is only a small part of the complex process of the renewal. I think that the multi-faceted minority (religious, ethnical and cultural), in spite of its negative effects which affect the financial situation and the human dignity as well could have a great benefit for doing theology. On the one hand, it urges us to a Bible- and piety-centred approach, echoing the "motto" of the classical antiquity: "ad fontes!". On the other hand, it gives us the advice to rediscover the values both of the early Christian theology and of European (including Hungarian) Reformation as of two periods of Church history of a special importance, in order to acquire a "toolbox" which could be an effective help in discerning the message of the Gospel, i.e., the testimony of the "only comfort".

We hope we made it clear that doing theology means also the shaping of a new life (both of the one doing theology and their readers), which is conceived and developing in the safety of the living-space of the New Covenant through Jesus, i.e., the Kingdom of God, which came close to us. This new life, i.e., the "Kingdom-membership" implies also a new understanding: one not only of the whole life but of the interpretation or definition of the essence of theological science as well. I dare to hope that such an interpretation of theology could strengthen the permanent renewal (=semper reformari) of the Hungarian Reformed Church of Transylvania and could help it become a more genuine witness of God's eternal, one and unique Kingdom.

\section{BIBLIOGRAPHY}

Amesius, Guilelmus: Medulla Theologica illustrata. Franequerae 1670.

Augustinus: De civitate Dei. VIII,1.

Barth, Karl: Church Dogmatics. I/1. (eds.: G. W. Bromiley - T. F. Torrance) T\&T. Clarck, Edinburgh 1975.

Busch, Eberhard: Drawn to Freedom. Christian Faith Today in Conversation with the Heidelberg Catechism. (transl. Rader, William), Eerdmans, Grand Rapids - Cambridge 2010.

Calvin, John: Institutes of the Christian Religion I 7,1. (tr. Battles, F. L.), Westminster Press 1960.

Gaál Botond: Scriptura valde prima. Source: https://silverprince99.wixsite.com/bgaal/tanulmny41 (accessed: 07. 05. 2021.)

Györkösy Alajos - Kapitánffy István - Tegyey Imre: Ógörög-magyar nagyszótár (Ancient GreekHungarian Dictionary). Akadémiai Kiadó (Academic Publisher House), Budapest 1993.

Martonfalvi Tóth György: Tanétó és Czáfoló theológiája. Debrecen, 1679.

McGrath, Alister: Bevezetés a keresztény teológiába (Christian Theology. An Introduction. $1^{\text {st }}$ edition). Osiris Kiadó, Budapest 1995.

McGrath, Alister: Christian Theology. An Introduction. $5^{\text {th }}$ edition. Wiley-Blackwell, 2011. 158.

McGrath, Alister: Christian Theology. An Introduction. $5^{\text {th }}$ edition. Wiley-Blackwell, 2011.

Pannenberg, Wolfhart: Rendszeres teológia, 1. Kötet (Systematic Theology. Volume I). Osiris Kiadó, Budapest 2005.

Pictetus, Benedictus: Medulla Theologiae Christianae Didacticae et Elencticae. Geneva 1711.

Tavaszy Sándor: Református keresztyén dogmatika. Protestáns Teológiai Intézet, Kolozsvár, 2006. 
Tillich, Paul: Rendszeres teológia. Osiris Kiadó, Budapest, 1996.

Török István: Dogmatika. Protestáns Teológiai Intézet, Kolozsvár 2006.

Vanhoozer, Kevin: A Drama-of-Redemption Model. In: Meadors Gary (ed): Four Views on Moving Beyond the Bible to Theology. Zondervan, Grand Rapids 2009.

Welker, Michael: Sola Scriptura? The Authority of the Bible in Pluralistic Environments. In: Strawn, B. A. - Bowen, N. R. (eds.): A God So Near. Essays on the Old Testament Theology in Honor of Patrick D. Miller. Eisenbrauns, Winona Lake 2003.

Wright, N. T.: How Can the Bible Be Authoritative. Source: http://ntwrightpage.com/Wright_ Bible_Authoritative.htm (accessed: 30. 10. 2014.)

Wright, N. T.: Scripture and the Authority of God. Harper Collin's ebooks. Chapter 8.

Wright, N. T.: The New Testament and the People of God. Fortress Press, Minneapolis 1992. 